\title{
A novel DNA-binding regulatory factor is mutated in primary MHC class II deficiency (bare lymphocyte syndrome)
}

\author{
Viktor Steimle, ${ }_{1}^{1}$ Bénédicte Durand, ${ }^{1,3}$ Emmanuèle Barras, ${ }^{1}$ Madeleine Zufferey, ${ }^{1}$ Martin R. Hadam, ${ }^{2}$ \\ Bernard Mach, ${ }^{1}$ and Walter Reith ${ }^{1,4}$ \\ ${ }^{1}$ Jeantet Laboratory of Molecular Genetics, Department of Genetics and Microbiology, University of Geneva Medical School, \\ Centre Médical Universitaire, Geneva 4, Switzerland; ${ }^{2}$ Kinderchirurgie, Kinderklinik, Medizinische Hochschule Hannover, \\ D-3000 Hannover 61, Germany
}

Regulation of MHC class II gene expression is an essential aspect of the control of the immune response. Primary MHC class II deficiency is a genetically heterogeneous disease of gene regulation that offers the unique opportunity of a genetic approach for the identification of the functionally relevant regulatory genes and factors. Most patients exhibit a characteristic defect in the binding of a nuclear complex, RFX, to the X box motif of MHC class II promoters. Genetic complementation of a B-lymphocyte cell line from such a patient with a cDNA expression library has allowed us to isolate RFX5, the regulatory gene responsible for the MHC class II deficiency. This gene encodes a novel DNA-binding protein that is indeed a subunit of the RFX complex. Mutations in the RFX5 gene have been characterized in two patients. Transfection of the patient's cells with the RFX5 cDNA repairs the binding defect and fully restores expression of all the endogenous MHC class II genes in vivo.

[Key Words: Bare lymphocyte syndrome; DNA-binding protein; expression cloning; MHC class II deficiency; RFX proteins; transcription factor]

Received January 26, 1995; revised version accepted March 14, 1995.

The elucidation of the molecular mechanisms controlling complex patterns of cell-specific, inducible, and developmentally regulated gene expression in higher eukaryotes is rendered difficult by the fact that in most instances there is no straightforward genetic approach permitting unambiguous identification of the functionally relevant trans-acting factors. Major histocompatibility complex $(\mathrm{MHC})$ class II gene regulation represents one of the rare systems in which such a genetic approach exists. It relies on the existence of a form of primary immunodeficiency, called MHC class II deficiency or the bare lymphocyte syndrome (BLS), that has been shown to result from defects in the regulation of $\mathrm{MHC}$ class II genes (for review, see Griscelli et al. 1993; Mach et al. 1994). Cell lines derived from patients afflicted with this disease of gene regulation have provided a unique genetic model system for the identification of genes and factors that control MHC class II gene expression.

In BLS, the genes encoding the $\alpha$ and $\beta$ chains of the HLA-DR, HLA-DQ, and HLA-DP MHC class II molecules are not expressed in any cell type. Because of the

\footnotetext{
${ }^{3}$ Present address: Centre de Génétique Moléculaire et Cellulaire, Centre National de la Recherche Scientifique (CNRS)-UMR 106, Université Claude Bernard, Lyon 1, 69642 Villeurbanne, France.

${ }^{4}$ Corresponding author.
}

essential role of these molecules in the presentation of exogenous antigens to CD4 helper $\mathrm{T}$ lymphocytes, and thus in the control of the immune response, the lack of $\mathrm{MHC}$ class II expression in BLS patients results in severe immunodeficiency (for review, see Griscelli et al. 1993; Mach et al. 1994). The genetic defects responsible for this lack in expression reside in genes encoding transacting regulatory factors that are essential for MHC class II gene transcription (De Préval et al. 1985). The same is true for certain in vitro-generated $\mathrm{MHC}$ class II negative cell lines (Gladstone and Pious 1978; Accolla 1983; Accolla et al. 1985; Calman and Peterlin 1987, 1988).

Despite an identical clinical phenotype, the cause of MHC class II deficiency has been found to be heterogeneous. Certain patients exhibit a characteristic defect in the binding of a nuclear factor, RFX, to the $\mathrm{X}$ box motif of MHC class II promoters, whereas in other patients RFX binds normally (Reith et al. 1988; Stimac et al. 1991; Herrero Sanchez et al. 1992; Hasegawa et al. 1993; Durand et al. 1994). These two distinct biochemical phenotypes have been found to correlate with the genetic heterogeneity of this disease (Table 1). At least three genetic complementation groups $\langle A, B$, and $C\rangle$ have been identified by cell fusion experiments (Hume and Lee 1989; Benichou and Strominger 1991; Seidl et al. 1992; Lisowska-Grospierre et al. 1994). The RFX-binding de- 
Table 1. Genetic and molecular heterogeneity in MHC class II deficiency

\begin{tabular}{|c|c|c|c|c|c|}
\hline \multirow{2}{*}{\multicolumn{2}{|c|}{$\begin{array}{l}\text { Complementation } \\
\text { group }\end{array}$}} & \multicolumn{3}{|c|}{ In vitro binding } & \multirow[b]{2}{*}{ Defect } \\
\hline & & RFX & $\mathrm{X} 2 \mathrm{BP}$ & NF-Y & \\
\hline A & $\begin{array}{l}\mathrm{RJ} 2.2 .5^{\mathrm{a}, \mathrm{b}} \\
\mathrm{BLS}^{\mathrm{b}} \\
\mathrm{BCH}^{\mathrm{b}}\end{array}$ & + & + & + & CIITA \\
\hline B & $\begin{array}{l}\mathrm{BLS} 1^{\mathrm{c}} \\
\mathrm{Ra}^{\mathrm{c}} \\
\mathrm{Na}^{\mathrm{c}}\end{array}$ & - & + & + & $\begin{array}{l}\text { RFX- } \\
\text { binding } \\
\text { activity }\end{array}$ \\
\hline $\mathrm{C}$ & $\begin{array}{l}\mathrm{SJO}^{\mathrm{c}} \\
\mathrm{TF}^{\mathrm{c}} \\
\mathrm{Ro}^{\mathrm{c}, \mathrm{d}}\end{array}$ & - & + & + & RFX5 \\
\hline
\end{tabular}

In vitro-generated class-II-negative B-cell line.

${ }^{b}$ Cell lines in which CIITA has been shown to be mutated (Steimle et al. 1993, and unpubl.)

'Patients in which binding of RFX is deficient (Reith et al. 1988; Herrero-Sanchez et al. 1992; Hasegawa et al. 1993, and unpubl.). ${ }^{\mathrm{d}}$ Patient allocated to group $\mathrm{C}$ in this paper.

fect is characteristic of patients from groups $B$ and $C$, but not of patients in group A (Table 1). The lack of RFXbinding activity in patients from groups $\mathrm{B}$ and $\mathrm{C}$ also correlates with an abnormal chromatin structure at the MHC class II promoter as judged from the pattern of DNase I hypersensitivity (Gönczy et al. 1989), and with an unoccupied MHC class II promoter phenotype in vivo (Kara and Glimcher 1991, 1993). The defect in RFX binding is highly specific and does not concern other MHC class II promoter-binding proteins such as the $\mathrm{Y}$ boxbinding protein NF-Y (Hooft van Huijsduijnen et al. 1990; Mantovani et al. 1992), X2 box-binding proteins such as c-Jun, c-Fos, hXBP1, mXBP, and X2bp (Liou et al. 1988, 1990; Andersson and Peterlin 1990; Ono et al. 1991 a,b; Sloan et al. 1992; Reith et al. 1994a), and several $\mathrm{X}$ box-binding proteins that are distinct from RFX (Reith et al. 1989, 1990, 1994c; Kouskoff et al. 1991; Herrero Sanchez et al. 1992). This has led us to suggest that the absence of RFX-binding activity is the molecular defect responsible for MHC class II deficiency in patients from groups B and C (Reith et al. 1988; Herrero Sanchez et al. 1992; Durand et al. 1994).

The gene mutated in BLS complementation group A has been cloned recently by an expression-cloning approach (Steimle et al. 1993). This regulatory gene encodes CIITA, an MHC class II trans-activator that is essential for both constitutive and $\gamma$-interferon (IFN- $\gamma$ )-induced expression of MHC class II genes (Steimle et al. 1993, 1994). Using the same strategy, we have now cloned a novel MHC class II regulatory protein, RFX5, by complementation of a BLS cell line exhibiting the characteristic RFX-binding defect (SJO in complementation group C). RFX5 is the $75-\mathrm{kD}$ subunit of the RFX complex. Transfection of RFX5 into cells from complementation group $\mathrm{C}$ restores binding of the RFX complex and reactivates expression of all the endogenous MHC class II genes. Mutations in the RFX5 gene have been characterized in two patients, SJO and Ro, in group C. These results demonstrate that mutations in the gene encoding the RFX5 subunit of RFX lead to MHC class II deficiency. More important, the data establish directly that this novel DNA-binding protein is an essential transcriptional activator of all members of the MHC class II multigene family. The fact that RFX5 is a functionally essential and highly specific trans-activator of MHC class II gene expression implies that experimental modulation of its activity could profoundly affect the control of the immune response. This suggests novel strategies for immunomodulation.

\section{Results}

Functional complementation of the BLS cell line SIO

The isolation of CIITA, the MHC class II trans-activator mutated in complementation group A, by complementation of the in vitro-generated mutant RI2.2.5 (Steimle et al. 1993) prompted us to apply the same strategy to BLS cell lines exhibiting a lack in RFX-binding activity. Compared with in vitro-generated mutants, such as RJ2.2.5, BLS cell lines tend to exhibit slow growth, high sensitivity to antibiotics, and low transfection efficiencies (V. Steimle and M. Zufferey, unpubl.). Therefore, appropriate modifications had to be made in the cell culture and selection conditions (see Materials and methods). The BLS cell line SJO in complementation group C was chosen because of its relatively favorable growth properties and stable phenotype. SJO cells transfected with the DRA-CD cDNA library (Steimle et al. 1993) and sorted twice for HLA-DR expression showed strong HLA-DR positivity in the cytofluorometric analysis (Fig. 1, panel 1). Plasmids were rescued from these complemented HLA-DR-positive SJO cells, amplified in Escherichia coli, and retransfected into SJO cells or into cells from complementation groups A and B. SJO cells transfected with the rescued plasmid pool reverted to a HLADR-positive phenotype in the absence of selection for re-expression of MHC class II molecules (Fig. 1, panel 2). On the other hand, transfection of the same plasmid preparation into cell lines from BLS complementation groups A (R/2.2.5) and B (BLS-1) had no effect on HLA class II expression (Fig. 1, panels 3,4), indicating that complementation is specific to group C.

Analysis of the rescued plasmid pool revealed the presence of at least four strongly enriched plasmid species containing cDNA inserts of $0.8,3.2,3.5$, and $5.4 \mathrm{~kb}$ (data not shown). The plasmid pool was then diluted 500 -fold with vector DNA and retransfected into SJO cells. After two rounds of sorting for HLA-DR expression, these secondary transfectants were again strongly MHC class II positive (data not shown). The plasmids rescued from these cells contained a single major cDNA insert of 3.5 $\mathrm{kb}$ (data not shown). Transfection of this CDNA into SIO confers a completely normal MHC class II positive phenotype. Expression of all three HLA class II isotypes (HLA-DR, HLA-DP, and HLA-DQ) is restored to levels similar to those observed in class II-positive cells such as Raji (Fig. 2A). The effect is specific for MHC class II 

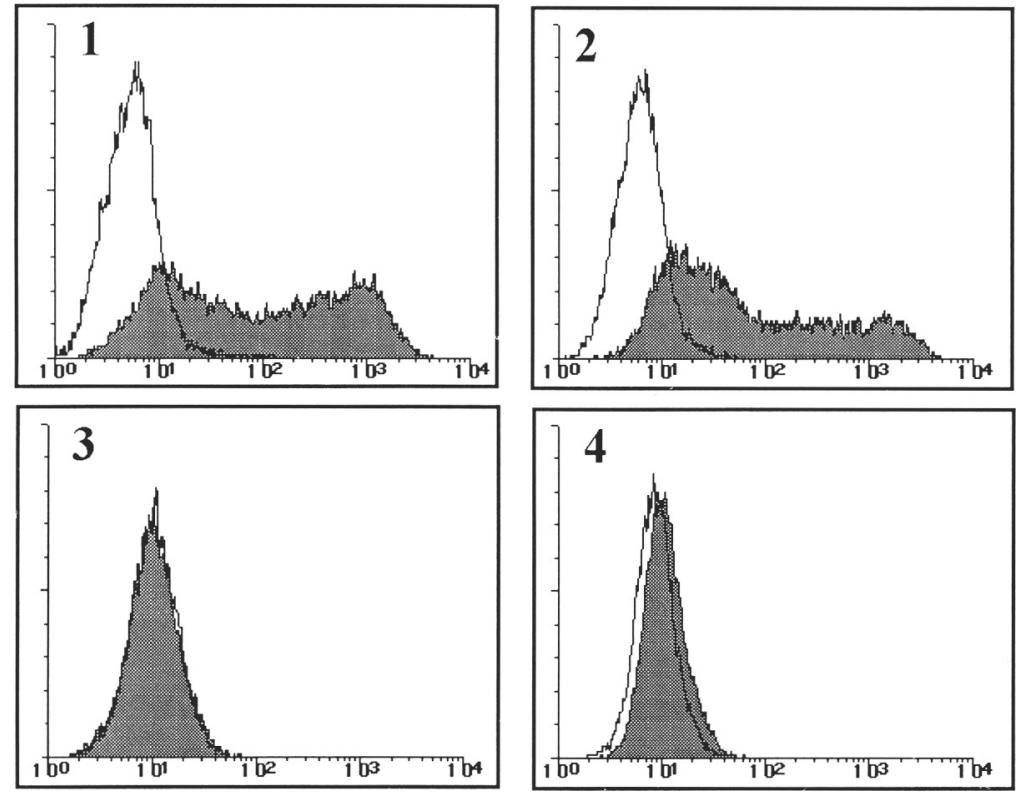

Figure 1. Expression cloning of RFX5. Analysis of HLA-DR expression on SJO cells that had been transfected with the DRA-CD cDNA library, selected for hygromycin resistance, and sorted twice for HLA-DR expression (1), and fresh SJO cells (2), RJ2.2.5 cells (3), or BLS-1 cells (4) that had been transfected with the plasmid pool rescued from the initial complemented SJO population and selected only for hygromycin resistance. Transfected cells (solid profiles) and control untransfected cells (open profiles) were stained with the HLA-DR-specific antibody and analyzed by FACScan. Untransfected cells used as negative controls were SJO $(1,2)$, RJ2.2.5 (3), and BLS-1 (4). expression because no change in the expression of HLA class I is observed (Fig. 2A). The cDNA was called RFX5 because sequence analysis (see below) indicated that it is the fifth member of a previously identified family of $\mathrm{X}$ box-binding proteins (RFX1, RFX2, RFX3, and RFX4), (Reith et al. 1994c).

Several BLS patients exhibiting a lack of RFX-binding activity have not yet been assigned to the existing complementation groups. B-cell lines from three of these patients (AH, SM, and Ro, Hadam et al. 1984) were transfected with RFX5. Expression of HLA-DR was restored efficiently in the Ro cell line (Fig. 2B), whereas the other two cell lines remained completely negative (data not shown). On the basis of this complementation experiment, Ro can be assigned to BLS complementation group C (Table 1).

\section{RFX5 is a novel member of the RFX family of DNA-binding proteins}

The nucleotide and deduced amino acid sequences of the RFX 5 cDNA are shown in Figure 3A. The sequence contains a 616-amino-acid open reading frame starting with the ATG codon at nucleotide 153 and ending at the TGA stop codon at nucleotide 2002. That the ATG at nucleotide 153 is the translation initiation codon is inferred from the fact that it is preceded by an in-frame TAA stop codon at nucleotide 112 . Moreover, with a purine at -3 , this ATG codon conforms to the Kozak consensus (Kozak 1989). The RFX5 protein has a predicted molecular mass of $65 \mathrm{kD}$. In vitro-translated RFX5 has an apparent molecular mass of $75 \mathrm{kD}$ in SDS-PAGE (data not shown).

A search for homology to protein sequences in available data bases revealed that RFX5 is the fifth member of a family of DNA-binding proteins (RFX1, RFX2, RFX3, and RFX4) that we have cloned previously (Reith et al. 1994c). RFX1-RFX4 can all bind specifically to the MHC class II $X$ box sequence by a 74-amino-acid DNA-binding domain that has been found to date only in RFX proteins (Reith et al. 1990, 1994c). RFX5 contains a 75-amino-acid sequence (Fig. 3A; amino acids 93-168) showing strong homology to this DNA-binding motif (Fig. 3B). Homology between RFX5 and RFX1-RFX4 is greater in the carboxy-terminal moiety of the motif $(73 \%)$ than in the amino-terminal moiety $(36 \%)$. This homology is lower than the $91 \%$ amino acid identity observed among the RFX1-RFX4 proteins; thus, until now, RFX5 is the most divergent member of the RFX family. In this respect it is striking that RFX5 does not show any significant homology to other conserved regions of RFX1-RFX4 (Reith et al. 1994c). In particular, there is no clear sequence homology with the dimerization domain of RFXl-RFX4 (Reith et al. 1990, 1994c). The only other feature of interest in the sequence of RFX5 is a proline-rich region situated downstream of the DNA-binding domain. RFX1 and RFX2 also contain regions rich in proline, but these show no homology to RFX5 and, in contrast to RFX5, are situated upstream of the DNA-binding domain (Reith et al. 1994c).

The DNA-binding domains of RFX1-RFX4 confer the ability of these proteins to bind specifically to the MHC class II X box. To determine whether this is also true for RFX5, electrophoretic mobility shift assays (EMSAs) were performed with in vitro-translated RFX5. No efficient binding could be obtained with full-length RFX5 (data not shown). On the other hand, a carboxy-terminally truncated RFX5 polypeptide containing the DNAbinding domain (amino acids 1-195) forms two proteinDNA complexes with the DRA X box (Fig. 4). Previous studies with truncated polypeptides containing the DNA-binding domain of RFX1 (Siegrist et al. 1993) sug- 


\section{A}
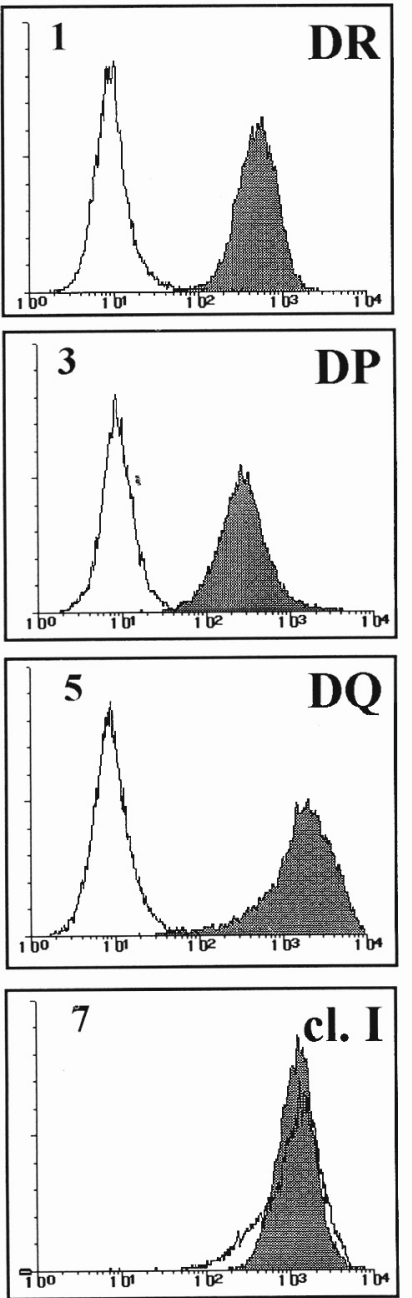

B

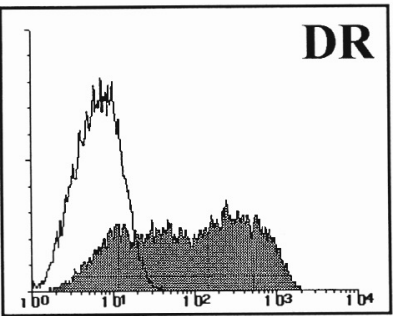

Figure 2. Complementation of SJO and Ro by RFX5. (A) RFX5 restores expression of all MHC class II genes in SIO. FACScan analysis of the expression of HLA-DR $(1,2)$, HLA-DP $(3,4)$, HLADQ $(5,6)$, and HLA class $I(7,8)$ on Raji cells (solid profiles in $1,3,5,7)$, SJO cells transfected with the DRA-CD/RFX5 expression vector (solid profiles in 2,4,6,8) and untransfected SJO cells (open profiles in 1-8). (B) RFX5 complements the BLS cell line Ro. FACScan analysis of the expression of HLA-DR on untransfected Ro cells (open profile) and on Ro cells transfected with the DRA-CD/RFX5 expression vector (solid profile).

gest that these two complexes are attributable to the binding of one (lower complex) or two (upper complex) truncated RFX5 molecules. Both complexes are specific, because their formation is eliminated by an excess of an $\mathrm{X}$-box competitor oligonucleotide, but not by an oligonucleotide containing a mutated $\mathrm{X}$ box or by an oligonucleotide containing an unrelated sequence (Fig. 4). These results demonstrate that the DNA-binding domain of RFX5 is functional and specific for the $\mathrm{X}$ box. The finding that full-length RFX5 does not bind efficiently on its own may reflect the fact that RFX5 binds normally to the MHC class II X box as a subunit of the multimeric RFX complex (see below). In this respect RFX5 behaves similarly to RFX3, which binds poorly on its own but very efficiently as a heterodimer with RFXl (Reith et al. 1994c). It should be mentioned, however, that RFX 5 does not contain a region showing clear homology with the dimerization domain identified in RFX1-3, suggesting that a different motif may be involved in the interaction between RFX5 and other subunits of the RFX complex.

\section{$R F X 5$ is present in the nuclear RFX complex}

The results presented above demonstrate (1) that RFX5 restores normal MHC class II gene expression in BLS cells that are deficient in the nuclear RFX complex, and (2) that RFX5 contains a DNA-binding domain conferring the ability to bind specifically to the $\mathrm{X}$ box. This suggested that RFX5 was likely to be present in the nuclear RFX complex. To investigate this, the RFX-deficient SJO cell line was transfected with an RFX5 expression vector. Nuclear extracts were prepared from these complemented SJO cells and tested for binding of the nuclear RFX complex by means of EMSA experiments. As a negative control we used nuclear extracts from SJO cells transfected with the vector lacking the RFX 5 cDNA insert. The results demonstrate that transfection with the RFX 5 expression vector restores binding of a nuclear complex that comigrates with the RFX complex detected in extracts from normal MHC class II-positive control cells (Fig. 5A). Moreover, the complemented SJO extract exhibits a unique feature that is highly characteristic of RFX. Namely, RFX binds cooperatively with the Y-boxbinding protein NF-Y such that a highly stable RFX/ NF-Y complex forms when these two proteins are allowed to bind together to an oligonucleotide containing both the X box and the Y box (Reith et al. 1994b). Formation of this RFX/NF-Y complex is restored efficiently in the complemented SJO extract (Fig. 5A).

To demonstrate directly that RFX5 is present in the restored RFX complex, we constructed an expression vector encoding an RFX5 protein that is tagged at its amino terminus with an epitope (HA) from influenza virus hemagglutinin. This HA-tagged RFX5 protein is completely functional; it restores a normal MHC class II-positive phenotype when transfected into SJO cells (data not shown). Nuclear extracts were prepared from SJO cells complemented with HA-tagged RFX5. EMSA experiments were then performed to determine whether an anti-HA antibody could recognize the restored RFX complex. Addition of the anti-HA antibody slows down migration of the RFX complex restored in cells trans- 
A

63

153
1

243
31

333

333
61

423

423
91
5

513
121

603
151$$
\begin{aligned}
& 693 \\
& 181
\end{aligned}
$$$$
783
$$

211

873
241

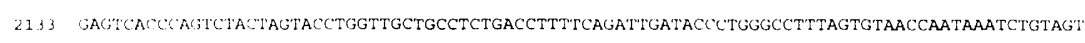

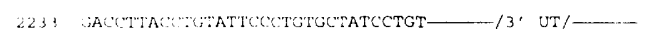

\section{B}

HRFX1 V Q W L L D N Y E T A E G V S L P R S T L Y C C H Y L L L H C C E E Q K L . E P V N A

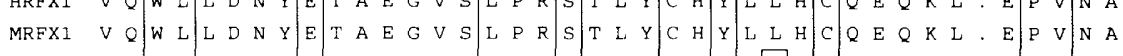
MRFX2 L Q W L L L D N

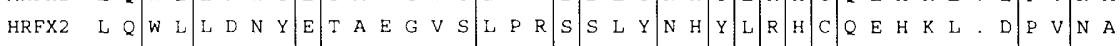
HRFX3 L $Q$ Q W L L L D N N Y E T T A E G G V S L L P R

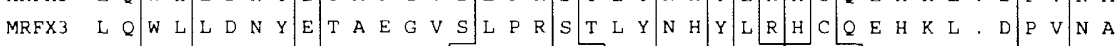

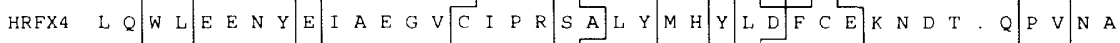

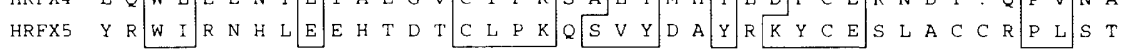

Figure 3. RFX5 belongs to the RFX family of $\mathrm{X}$-box-binding proteins. $|A|$ Nucleotide and predicted amino acid sequences of RFX5. The in-frame TAA stop codon preceding the translation initiation codon and the TGA stop codon terminating the open reading frame of RFX5 are underlined. The box encloses a 75-amino-acid sequence showing homology to the DNAbinding domain (DBD) of the RFX family (see $B$ ). The peptide sequence (EIFPDIK) obtained from the $75-\mathrm{kD}$ polypeptide present in the purified RFX fraction and regions rich in proline $(\mathrm{P})$ are underlined. The deletion (nucleotides 386-390) in SJO and the two point mutations (at nucleotides 1032 and 1378) in Ro are indicated in lowercase letters (see Fig. 6). The 3'-untranslated region $\left(3^{\prime}\right.$ UT) has not been sequenced completely. $(B)$ Sequence alignment among the DNA-binding domains of RFX1, RFX2, RFX3, RFX4, and RFX5. For RFXl-RFX4 both the human $\langle\mathrm{H}\rangle$ and mouse $(\mathrm{M})$ sequences are shown. Identical and conservative $(\mathrm{I} / \mathrm{L} / \mathrm{V}, \mathrm{R} / \mathrm{K}, \mathrm{S} / \mathrm{T}, \mathrm{N} / \mathrm{Q}$, and $F / Y$ ) amino acids shared by RFX5 and at least one other RFX protein are enclosed by boxes. The points indicate a gap introduced to maximize homology. The average percentage of homology between RFX 5 and the other RFX proteins is indicated for the amino- $(t o p, 36 \%)$ and carboxy-terminal (bottom, 73\%) moieties of the DNAbinding domain.

fected with HA-tagged RFX5 (Fig. 5B). This effect is specific, as the anti-HA antibody has no effect on migration of the RFX complex restored in cells transfected with untagged RFX5 (Fig. 5B, top), or on migration of NF-Y (Fig. 5B, bottom). Therefore, it can be concluded that RFX5 is present in the restored RFX complex. 
The native RFX complex has been purified by affinity chromatography (Durand et al. 1994). The purified fraction contains two polypeptides, of 75 and $36 \mathrm{kD}$, that are good candidates for RFX (Durand et al. 1994). The 75-kD polypeptide has the same apparent molecular mass as RFX5. Therefore, we obtained the amino acid sequence of a tryptic peptide derived from this $75-\mathrm{kD}$ polypeptide. The sequence obtained is found within the DNA-binding domain of RFX5 (see Fig. 3), thus providing formal proof that RFX5 is present in RFX. Cross-linking studies have shown that the $36-\mathrm{kD}$ polypeptide present in the purified fraction is also part of the nuclear RFX complex (Durand et al. 1994). Thus, RFX is a multimeric protein consisting of at least two different subunits, RFX5 and the 36$\mathrm{kD}$ polypeptide.

\section{The RFX5 gene is mutated in patients $S J O$ and Ro}

RNase protection experiments using several probes demonstrated that RFX 5 mRNA is expressed at normal levels in cell lines (SJO and Ro) from complementation group C (data not shown). To identify the mutation affecting RFX5 in SJO, five full-length RFX5 cDNA clones were isolated from an SJO cDNA library and sequenced. All five clones contain a deletion of 5 nucleotides (nucleotides 386-390) situated upstream of the DNA-binding domain (Fig. 6A). This deletion leads to a frameshift followed by a premature stop codon at nucleotide 410 and, thus, does not allow synthesis of a functional RFX5 protein (Fig. 6A). Transfection experiments have shown that the 5-nucleotide deletion completely abolishes the ability of RFX5 to restore MHC class II gene expression in SJO cells (data not shown).

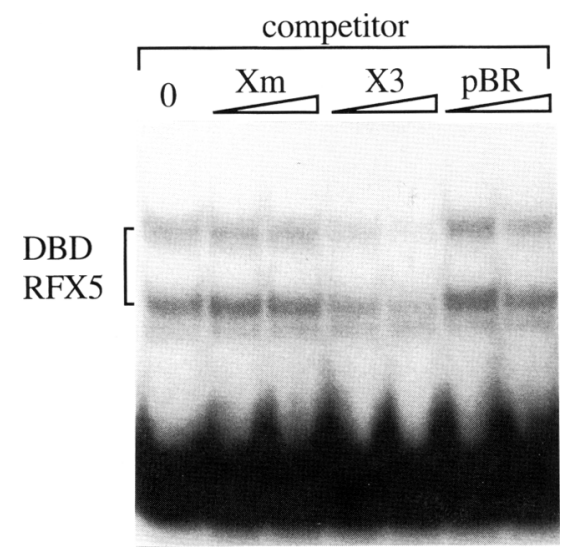

Figure 4. The DNA-binding domain of RFX5 binds specifically to the MHC class II X box. A truncated RFX5 polypeptide containing the DNA-binding domain (DBD RFX5, amino acids 1-195) was synthesized in vitro and tested in EMSA using the $\mathrm{X} 3$ oligonucleotide as probe. Specific protein-DNA complexes formed by DBD RFX5 are indicated at left. Binding reactions contained a 10- or 50-fold molar excess of a specific X-box oligonucleotide $(\mathrm{X} 3)$, an oligonucleotide containing a mutated $\mathrm{X}$ box $(\mathrm{Xm})$, or a nonspecific pBR322 oligonucleotide (pBR). No competitor oligonucleotide was added in lane 0 .
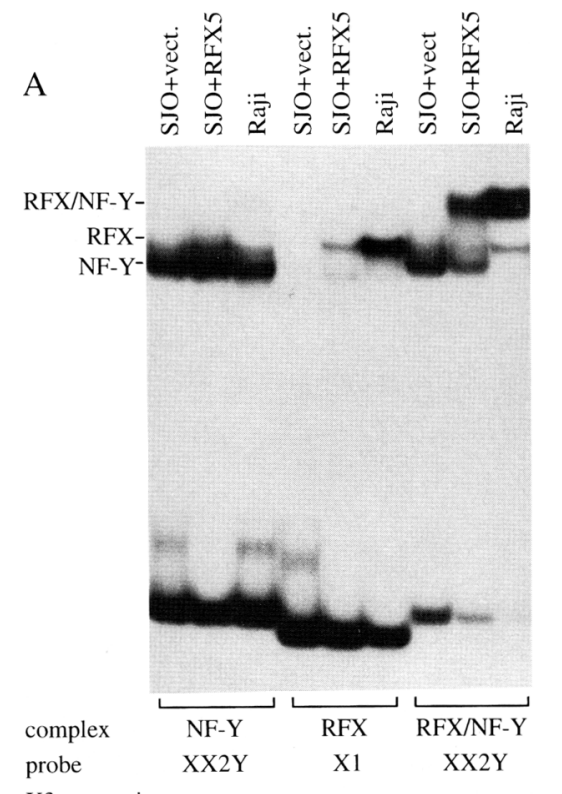

B
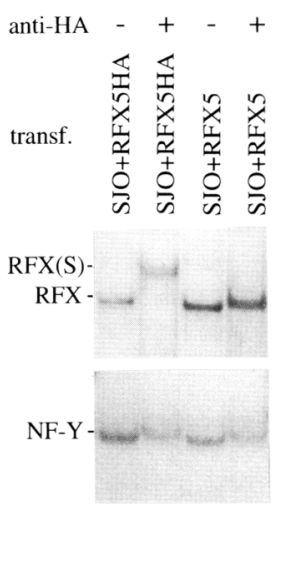

$\mathrm{X} 3$ competitor +

C
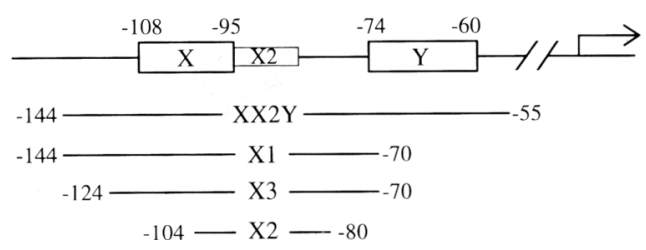

Figure 5. Binding of the RFX complex is restored in SJO cells transfected with RFX5. (A) Binding of NF-Y, RFX, and RFX/ NF-Y complexes was analyzed by EMSA using nuclear extracts from Raji, SJO cells complemented with the DRA-CD/RFX 5 expression vector (SJO + RFX5), or SJO cells transfected with the DRA-CD vector lacking a cDNA insert (SJO + vect.). Positions of protein-DNA complexes caused by binding of NF-Y, RFX, and RFX/NF-Y are indicated at left. DNAs used as probes were the XX2Y DRA promoter fragment for the NF-Y and RFX/NF-Y complexes, or the XI DRA oligonucleotide for the RFX complex (see $C$ ). To obtain either NF-Y or RFX/NF-Y complexes with the $\mathrm{XX} 2 \mathrm{Y}$ probe, binding reactions were done, respectively, in the presence $|+|$ or absence $|-|$ of $100 \mathrm{ng}$ of the DRA X3 competitor oligonucleotide (see $C$ ). All binding reactions also contained an $\mathrm{X} 2$ competitor oligonucleotide to avoid interference with proteins binding to the $\mathrm{X} 2$ box (see Materials and methods and $C$ ). (B) Binding of RFX (top) and NF-Y (bottom) were analyzed by EMSA as in $A$ using the XX2Y oligonucleotide and nuclear extracts from SJO cells transfected with the EBO-pLPP/RFX5 (SJO+RFX5) or EBO-pLPP/RFX5HA (SJO + RFX5HA) expression vectors. Binding reactions were done in the absence $(-)$ or presence $(+)$ of the anti-HA monoclonal antibody. Only the regions of the gels containing the protein-DNA complexes are shown; binding of RFX and NF-Y was analyzed in separate reactions using the same extracts. RFX(S) indicates the RFX complex supershifted by the anti-HA antibody. $|C|$ Schematic representation of the DRA promoter. The $\mathrm{X}, \mathrm{X} 2$, and $\mathrm{Y}$ boxes are represented by boxes. Coordinates of the $X$ and $Y$ boxes, and of the DRA promoter fragments used as probes (XX2Y and $\mathrm{X} 1)$ or as an $\mathrm{X}$ box-specific competitor $(\mathrm{X} 3)$ in $A$ and $B$ are indicated. The $\mathrm{X} 2$ oligonucleotide was included as competitor in all binding reactions to avoid interference with $\mathrm{X} 2$ binding proteins \{see Materials and methods). 


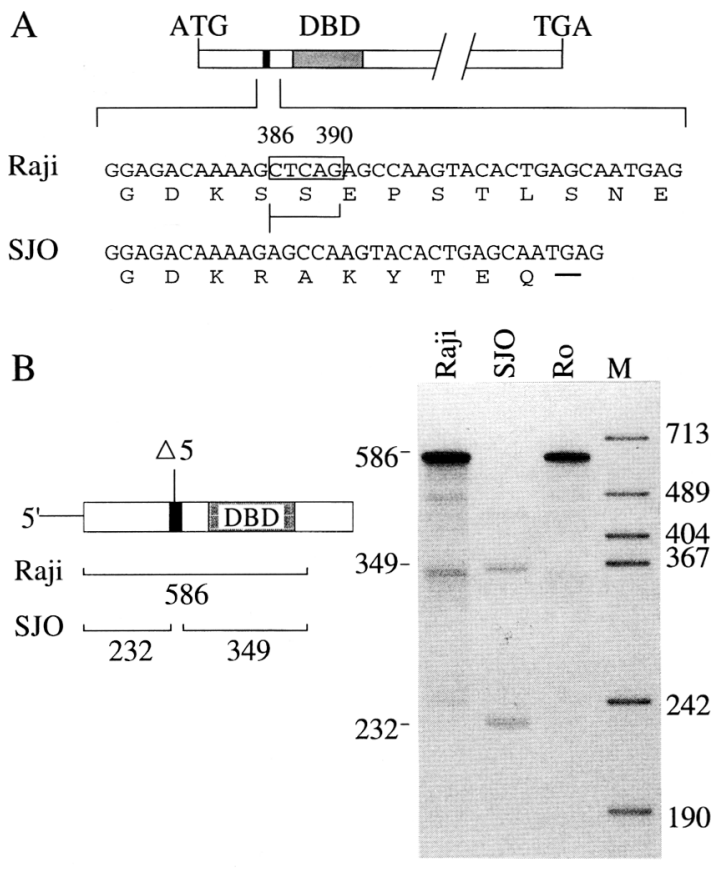

C

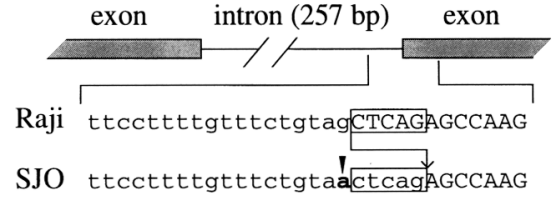

D

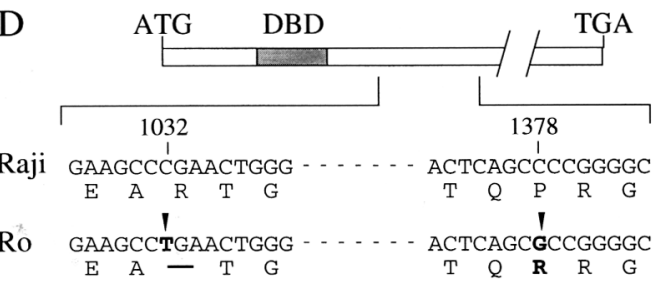

To investigate the origin of the 5-nucleotide deletion, the corresponding region was amplified by PCR from genomic DNA. This revealed the existence of an intron situated precisely at the $5^{\prime}$ end of the sequence that is deleted in SJO (Fig. 6C). The sequence of seven independently subcloned PCR products from SJO indicated that the mutation affecting the RFX5 gene is heterozygous. In one allele there is a $\mathrm{G} \rightarrow \mathrm{A}$ mutation within the splice acceptor site at the $3^{\prime}$ end of the intron (Fig. 6C). This mutation leads to the use of a cryptic splice acceptor site situated 5 nucleotides downstream of the one used normally and, hence, gives rise to the RFX5 mRNA containing the 5-nucleotide deletion. In the second SIO allele, the splice acceptor site has the wild-type sequence.

To investigate whether the second allele in SJO could give rise to functional RFX5 mRNA, RNase protection experiments were performed. Using a probe encompassing the $5^{\prime}$ end of the coding region (including the translation initiation codon, the 5-nucleotide deletion, and
Figure 6. Mutation of RFX5 in SJO and Ro. (A) RFX5 cDNA clones from contain a 5-nucleotide deletion (nucleotides 386-390) situated upand the use of a premature out-of-frame stop codon (underlined). The (B) SJO and acion sequences of this region are shown for Raji iments were performed using a probe encompassing the 5-nucleotide deletion present in SJO cDNA clones. Total RNAs from the normal MHC class II-positive B-cell line Raji and from the BLS cell lines SJO and Ro were Ro. This full-length protected fragment of 586 nucleotides, which corresonds to intact RFX5 mRNA, is not detected in SJO. In SJO, all of the probe in the two fragments of 232 and 349 nucleotides derived from mRNA containing the 5 -nucleotide deletion. Bands comigrating with 232- and 349-nucleotide fragments are not present in Raji or Ro. Moecular mass markers are shown in lane $M .(C)$ The 5-nucleotide deletion in SIO results from a $G \rightarrow$ A mutation (arrowhead) in a splice acceptor site of ite situated 5 nucleotides downstream and, hence, in the loss of 5 nucle(boxed) from the aberrantly spliced mRNA. Nucleotide sequences of tides) Exon; (lowercase nucleotides), intron. $(D)$ Mutation of the RFX5 gene Ro. The RFX5 gene in Ro contains two homozygous point mutations arrowheads|. A $\mathrm{C} \rightarrow \mathrm{T}$ mutation at nucleotide 1032 changes an arginine codon (GA) into a premature stop codon (TGA), and a C $\rightarrow$ G mutation at CGC). Nucleotide and amino acid sequences of the two regions are shown or Raji and Ro.

the entire DNA-binding domain|, no full-length protected fragment of 586 nucleotides corresponding to intact RFX5 mRNA is detected in SJO (Fig. 6B). Only the two protected fragments of 349 and 232 nucleotides derived from RFX5 mRNA containing the 5-nucleotide deletion are detected (Fig. 6B). Protected fragments of 349 and 232 nucleotides are not detected in Raji or in patient

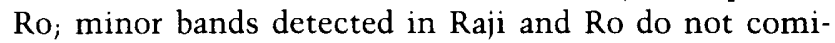
grate with the protected fragments in SJO (Fig. 6B). These results demonstrate that the second SJO allele does not give rise to full-length functional RFX 5 mRNA. This could result from a variety of different defects including point mutations, deletions, or insertions leading to either a lack of transcription, a profoundly perturbed pattern of splicing or a strongly destabilized transcript.

In contrast to SJO, normal levels of intact RFX5 mRNA are detected in patient Ro (Fig. 6B). To characterize the mutation affecting the RFX5 gene in Ro, four full-length cDNA clones were isolated from a Ro cDNA library. All four cDNAs contain two-nucleotide differences with respect to the wild-type Raji sequence (Fig. 6D). A C $\rightarrow \mathrm{T}$ mutation at nucleotide 1032 changes an arginine codon (CGA) to a premature stop codon (TGA) and, thus, leads to a severely truncated RFX5 protein. Downstream of this nonsense mutation, a $\mathrm{C} \rightarrow \mathrm{G}$ change at nucleotide 1378 replaces a proline codon (CCC) by an arginine codon (CCG). PCR amplification of the corresponding genomic DNA from Ro and his parents has shown that Ro is homozygous for both mutations, whereas both parents are heterozygous (data not shown).

\section{Discussion}

MHC class II deficiency (or BLS) represents one of the 
very few examples of a human genetic disease of gene regulation. It is attributable to defects in regulatory factors that are essential for both constitutive and IFN- $\gamma$ inducible expression of MHC class II genes (De Préval et al. 1985, 1988; Griscelli et al. 1993; Mach et al. 1994). BLS patients have been classified into three different complementation groups corresponding to three distinct MHC class II gene trans-activating factors (Hume and Lee 1989; Benichou and Strominger 1991; Seidl et al. 1992; Lisowska-Grospierre et al. 1994). Therefore, BLS provides an ideal model system for the identification of proteins that control transcription of MHC class II genes. The availability of such regulatory mutants permits the identification of relevant transcription factors on the basis of a powerful functional criterion, namely, the ability to complement the genetic defect. Such genetic complementation approaches have enormous advantages over biochemical techniques that identify potential transcription factors solely on the basis of their affinity for their cognate target sites in promoters or enhancers. Such binding studies are notorious for leading to the cloning of factors that bind to specific target sites in vitro but are not necessarily functionally relevant in vivo. The X-box region of MHC class II promoters is a good illustration of this point: Several different DNA-binding proteins have been identified on the basis of their ability to bind in vitro to the X box (Calman and Peterlin 1988; Reith et al. 1989, 1990, 1994c; Tsang et al. 1990; Kouskoff et al. 1991 ) or the X2 box (Liou et al. 1988, 1990; Andersson and Peterlin 1990; Ono et al. 1991a,b; Sloan et al. 1992; Reith et al. 1994a), but none of these have yet been shown directly to be trans-activators of MHC class II genes.

BLS cells in complementation groups B and C exhibit a characteristic lack in RFX binding activity (Reith et al. 1988; Stimac et al. 1991; Herrero Sanchez et al. 1992; Hasegawa et al. 1993; Durand et al. 1994). Here, we have used an expression cloning strategy to isolate the gene that is mutated in complementation group C (Fig. 1) and, therefore, have elucidated one of the molecular defects responsible for the RFX-deficient BLS phenotype. This gene, RFX5, encodes the 75-kD subunit of the RFX complex (Figs. 3 and 5). Transfection of RFX5 into BLS cells from group $C$ repairs the RFX-binding defect (Fig. 5) and restores a completely normal MHC class II-positive phenotype (Fig. 2). Mutations affecting the RFX5 gene have been characterized in two patients, SJO and Ro (Fig. 6). The complementation approach has provided direct proof that mutations leading to a deficiency in RFX-binding result in the BLS disease. More important, it has allowed us to isolate a novel DNA-binding factor that is essential for expression of MHC class II genes in all cell types and, thus, is crucial for the control of the immune response. The fact that fibroblasts from RFX-deficient BLS patients cannot be induced to express MHC class II genes by IFN- $\gamma$ (De Préval et al. 1988) indicates that RFX5 is required for inducible expression as well as constitutive expression.

An intriguing feature of the BLS disease is that very different molecular defects lead to an identical pheno- type and symptomatology. Recently, we have shown that in patients in complementation group $\mathrm{A}$ the gene that is mutated is CIITA, a non-DNA-binding trans-activator (Steimle et al. 1993). CIITA is expressed in a cellspecific manner and has been identified as the obligatory mediator of IFN- $\gamma$-induced MHC class II expression (Steimle et al. 1994). On the other hand, in complementation group $\mathrm{C}$ we show here that the defect resides in RFX5, a novel DNA-binding protein. Both RFX5 mRNA and the RFX complex are expressed in a wide variety of cell types, including MHC class II-negative cells, and are not induced by IFN- $\gamma$ (data not shown). In contrast to CIITA, therefore, RFX5 appears to be expressed constitutively. Considering the strikingly different modes of action and expression of CIITA and RFX5, it is of interest that mutations disrupting these two trans-activators have phenotypically and clinically undistinguishable effects.

Previous attempts to isolate cDNAs encoding the RFX complex had yielded the X-box-binding proteins called RFX1, RFX2, RFX3, and RFX4. Although clearly distinct from the RFX complex, these proteins exhibit very similar DNA-binding specificity (Reith et al. 1988, 1990, 1994c; Kobr et al. 1990; Herrero Sanchez et al. 1992). This led us to suggest that the RFX complex belongs to the same family (Herrero Sanchez et al. 1992; Reith et al. 1994c). Sequence analysis of RFX5 has confirmed this interpretation. RFX5 contains a functional DNA-binding domain showing strong homology to that of the other cloned RFX1-RFX4 proteins and, thus, is the fifth member of the family. A potential sixth member is represented by a gene in Saccharomyces cerevisiae, which contains a segment showing striking similarity to the RFX DNA-binding domain, indicating that this motif has been conserved strongly throughout evolution (P. Emery, B. Mach, and W. Reith, unpubl.). This growing family of novel DNA-binding proteins is consequently becoming increasingly important and widespread.

The finding that RFX5 is a member of the RFX family has two important implications. First, as suggested earlier, the MHC class II X box should be redefined as an imperfect variant of inverted repeat motifs referred to as EF-C or MDBP sites, which are the natural target sites for RFX1-RFX4 (Siegrist et al. 1993; Reith et al. 1994c). Second, as observed for the RFX1-RFX3 proteins (Reith et al. 1990, 1994c), RFX probably binds as a dimeric complex. Purification of RFX suggests strongly that it is a multimeric protein consisting of the 75-kD RFX5 subunit and a second subunit of $36 \mathrm{kD}$ (Durand et al. 1994). The $36-\mathrm{kD}$ protein is present in RFX as it cross-links specifically to the $\mathrm{X}$ box in extracts from cells containing normal RFX-binding activity, but not in RFX-deficient BLS extracts (Durand et al. 1994).

RFX-binding activity is lacking in nuclear extracts from cells in complementation group B as well as in group $C$, indicating that at least two different genetic defects can lead to a defect in RFX binding. Furthe more, binding of RFX is also deficient in the in vitro-generated regulatory mutant 6.1.6 (Stimac et al. 1991; W. Reith and B. Mach, unpubl.), which may belong to a complementation group distinct from groups $\mathrm{B}$ and $\mathrm{C}$ (Benichou and 
Strominger 1991; Seidl et al. 1992). Thus, the 6.1.6 cell line may represent a third genetic defect leading to a lack of RFX-binding activity. In view of this genetic heterogeneity, it is of interest that RFX consists of at least two subunits. We have shown here that the RFX5 subunit is mutated in BLS patients in group C. It is tempting to speculate that a second RFX-deficient complementation group could be attributable to mutations affecting the second $36-\mathrm{kD}$ subunit of RFX. An additional form of the RFX-binding defect could result from mutations in either a third subunit or in a gene encoding a cofactor or modifying activity required for binding of RFX.

Although the binding defect observed in BLS cells is restricted to RFX, all of the MHC class II promoter elements, including the $\mathrm{X}, \mathrm{X} 2$, and $\mathrm{Y}$ boxes, are unoccupied in vivo in these cells (Kara and Glimcher 1991, 1993). An explanation for this apparent paradox has been provided recently by experiments demonstrating that RFX forms strongly stabilized higher order complexes with the $\mathrm{X} 2$ box-binding protein $\mathrm{X} 2 \mathrm{bp}$ and the $\mathrm{Y}$ box-binding protein NF-Y (Durand et al. 1994; Reith et al. 1994a,b). Therefore, RFX plays a key role in promoting occupation of the MHC class II promoter in vivo by participating in cooperative binding interactions that are required to allow access of X2bp and NF-Y to their cognate target sites. These cooperative interactions also provide an explanation for the observation that although RFX is essential for coordinate expression of all MHC class II genes, it cannot bind efficiently on its own to the $\mathrm{X}$ boxes of certain MHC class II promoters, such as those of the DQA, DRB1, and DRB3 genes (Kobr et al. 1990; Emery et al. 1993; Reith et al. 1994a). The higher order complexes formed by RFX, X2bp, and NF-Y stabilize the interaction of RFX with such low affinity X boxes (Emery et al. 1993; Reith et al. 1994a, and unpublished data).

Like CIITA, RFX5 exhibits two striking properties that are unusual for transcription factors. First, the complete lack of MHC class II expression in all cell types and tissues of BLS patients demonstrates that RFX5 is absolutely essential and that no bypass is possible. This is particularly surprising because RFX 5 belongs to a family of related DNA-binding proteins that might be expected to exhibit a certain amount of redundancy in their function. Second, the absence of MHC class II expression is the only phenotype detectable in BLS patients and, therefore, RFX5 seems to be highly specific for MHC class II genes. These two features identify RFX5 and CIITA as potential targets for novel immunomodulators. Interference with the function of these two trans-activators might be expected to be a highly efficient and specific means of modifying MHC class II expression and thus of modulating the immune response.

\section{Materials and methods}

Cells

SJO (Casper et al. 1990; Bull et al. 1990; gift of Dr. J. Gorski), Ro (Hadam et al. 1984, 1986), BLS-1 (Hume et al. 1989; gift of Dr. J.S. Lee), R.J.2.2.5 (Accolla 1983); gift of Dr. R.S. Accolla), and Raji were grown in RPMI 1640 medium supplemented with
$10 \%$ fetal calf serum (FCS), penicillin, streptomycin, and glutamine. Cells were incubated at $37^{\circ} \mathrm{C}$ in $5 \% \mathrm{CO}_{2}$.

\section{Expression cloning}

The vector system, cDNA libraries, and general selection strategies have been described (Steimle et al. 1993). Modifications in the cell culture conditions were necessary because of the use of a patient's cell line. Briefly, 40 million SJO cells were transfected by electroporation with $20 \mu \mathrm{g}$ of plasmid DNA from the DRA-CD or DV libraries of Raji cDNA described previously (Steimle et al. 1993). Hygromycin selection was started $48 \mathrm{hr}$ after transfection, in increasing steps to a final concentration of $100 \mu \mathrm{g} / \mathrm{ml}$. A first round of selection for HLA-DR expression with the 2.06 antibody and magnetic beads (Dynal) was carried out after 7 days. Hygromycin selection was interrupted for 2 weeks after selection to enable cell survival. Complemented MHC class II-positive SJO cells were only obtained using the DRA-CD libraries. SJO cells transfected with DV libraries did not survive the sorting/selection procedure in repeated experiments, even with strongly reduced hygromycin concentrations.

Plasmid rescue and transfection into E. coli DH10.B cells (GIBCO-Life Technologies) were done as described (Steimle et al. 1993). To facilitate isolation of the plasmid (pDRA-CD/ RFX5) responsible for complementation, the plasmid pool rescued from the initial SJO transfectants was diluted 500-fold with EBO-Sfi vector DNA (Steimle et al. 1993) and retransfected into SJO cells. These secondary transfectants were then sorted twice for HLA-DR expression.

\section{DNA sequencing and sequence analysis}

The insert of pDRA-CD/RFX5 was transferred into a Bluescript plasmid (Stratagene) and sequenced on both strands using a T7 DNA polymerase sequencing kit (Pharmacia). The nucleotide and amino acid sequences of RFX5 were tested for homology to sequences in the EMBL (release 40), GenBank (release 86), SwissProt (release 29), and dbEST data bases. Sequence analysis was performed with $\mathrm{PC} /$ gene release 6.80 (Intelligenetics), the BLAST server (Altschul et al. 1990), and the PROSITE dictionary (Bairoch 1992).

\section{Flow cytometric analysis}

The following monoclonal antibodies were used: the HLA-DR specific antibody 2.06 (Charron and McDevitt 1979), the HLADQ specific antibody Tü22 (Ziegler et al. 1986; gift from Dr. A. Ziegler), the HLA-DP specific antibody B7/21 (Watson et al. 1983; gift from Dr. N. Reinsmoen, University of Minnesota, Minneapolis), and the HLA class I specific antibody W6.32 (Serotec, Oxford, England). Staining was done as described (Steimle et al. 1993). Viable cells $(10,000)$ were analyzed using a FACScan flow cytometer (Beckton Dickinson). Dead cells were excluded from the analysis by staining with propidium iodide and by their forward and sideways light-scattering properties.

\section{RFX5 expression plasmids}

To facilitate construction of the EBO-pLPP/RFX5 and EBOpLPP/RFX5HA expression plasmids, the insert from pDRACD/RFX5 was first cloned into the SalI site of a Bluescript plasmid (Stratagene). Using a PCR-based strategy, the 5'-untranslated region of the RFX5 insert was removed and replaced with an NdeI site at the translation initiation codon. This NdeI site was then used to insert an NdeI-compatible doublestranded oligonucleotide (upper strand, 5'- TATGTACCCA- 
TACGATGTTCCAGATTACGCTAGCTTGGGTGGTCC3'; lower strand 5'-TAGGACCACCCAAGCTAGCGTAATCTGGAACATCGTATGGGTACA-3'), which adds 15 amino acids (MYPYDVPDYASLGGP) to the amino terminus of RFX5. These 15 amino acids contain an HA epitope (underlined) (Field et al. 1988|. The oligonucleotide was designed such that the NdeI site is maintained only at the $5^{\prime}$ end of the HA tag. The NdeI sites at the $5^{\prime}$ ends of both the HA-tagged and untagged RFX5 constructs were then used to insert an oligonucleotide designed to optimize the Kozak consensus sequence of the translation initiation codon (GCCACTATGG). The untagged and HA-tagged RFX5 cDNAs were then inserted into the EBOpLPP expression plasmid (Spickofsky et al. 1990; gift from Dr. R.F. Margolskee/ to generate EBO-pLPP/RFX5 and EBO-pLPP/ RFX5HA, respectively.

\section{In vitro transcription/translation}

For in vitro transcription/translation, the modified RFX 5 cDNA containing an NdeI site at the translation initiation codon (see above) was inserted into pT7-7 (Tabor and Richardson 1985). This plasmid was linearized with $X h o I$, which cuts at nucleotide 741 (amino acid 195) within RFX5. The linearized plasmid was then transcribed with T7 RNA polymerase, and the resulting RNA was translated in an in vitro translation system (Promega), as described (Reith et al. 1990), to generate the truncated 195-amino-acid RFX5 polypeptide used in EMSA experiments.

\section{Nuclear extracts, EMSAs, and oligonucleotides}

Nuclear extracts were prepared from Raji cells as described (Shapiro et al. 1988). Nuclear extracts from transfected SJO cells were prepared as follows. Cells $\left(10 \times 10^{6}\right)$ were washed with PBS and resuspended in $400 \mu \mathrm{l}$ of $0.3 \mathrm{M}$ sucrose in $\mathrm{HB} \mid 15 \mathrm{mM}$ HEPES (pH 7.9), $10 \%$ glycerol, $60 \mathrm{~mm} \mathrm{KCl}, 15 \mathrm{~mm} \mathrm{NaCl}, 0.15 \mathrm{~mm}$ spermine, $0.5 \mathrm{~mm}$ spermidine, $0.5 \mathrm{~mm}$ EDTA|. Cells were then lysed by adjusting the suspension to $0.5 \% \mathrm{NP}-40$ and vortexing for $10 \mathrm{sec}$. Nuclei were pelleted for $5 \mathrm{~min}$ at $2000 \mathrm{~g}$ through a 0.9 $M$ sucrose cushion in $\mathrm{HB}$. The nuclear pellet was resuspended in $60 \mu$ l of $20 \mathrm{~mm}$ HEPES (pH 7.9), $20 \%$ glycerol, $0.4 \mathrm{M} \mathrm{KCl}, 1 \mathrm{~mm}$ EDTA, $1 \mathrm{mM}$ DTT, and $1 \mathrm{~mm}$ PMSF and left on ice for $15 \mathrm{~min}$. The suspension was then centrifuged for $5 \mathrm{~min}$ at $15000 \mathrm{~g}$, and the supernatant (nuclear extract) was stored at $-20^{\circ} \mathrm{C}$. Protein concentrations were determined according to the method of Bradford.

EMSAs with crude nuclear extracts or in vitro-translated RFX5 were performed as described (Reith et al. 1988; Kobr et al. 1990; Herrero Sanchez et al. 1992; Durand et al. 1994). Under these conditions, very little if any other $\mathrm{X}$ box-binding activities are detected in crude nuclear extracts. With respect to the previously published conditions, the following modifications have been introduced. All binding reactions performed with crude nuclear extracts contained $100 \mathrm{ng}$ of the $\mathrm{W}$ oligonucleotide and $100 \mathrm{ng}$ of the pBRm oligonucleotide to avoid interference with W-box-binding proteins and other X-box-binding proteins such as RFXl-RFX4 (Reith et al. 1994c). BSA (5 mg/ml) and NP-40 $(0.1 \%)$ were added to binding reactions. Conditions for formation of the RFX/NF-Y complex (Fig. 5A) have been described in detail elsewhere (Reith et al. 1994b). The molar excess of competitor oligonucleotides added during the binding reactions are indicated in the figure legends. For supershift experiments, 20$\mu \mathrm{l}$ binding reactions were set up as usual, allowed to proceed for $30 \mathrm{~min}$ at $20^{\circ} \mathrm{C}$, supplemented with $1 \mu \mathrm{l}$ of anti-HA monoclonal antibody (12CA5; obtained from Gail G. Fieser, Scripps Clinic
Research Institute, La Jolla, CA), and then continued for $15 \mathrm{~min}$ at $20^{\circ} \mathrm{C}$ before gel electrophoresis.

Double-stranded probes and competitor oligonucleotides used for EMSA were prepared as described previously (Reith et al. 1988). The X1 and X3 oligonucleotides cover, respectively, nucleotides -144 to -70 and -124 to -70 of the DRA promoter. $\mathrm{Xm}$ is identical to $\mathrm{X} 3$ except that the $\mathrm{X}$ box has been replaced with a random sequence (Reith et al. 1990). The X2 oligonucleotide contains the DRA X2 box (Herrero Sanchez et al. 1992). The XX2Y DRA promoter fragment $(-150$ to -60$)$ was excised with HindIII and BgIII from the pDRsyn plasmid (Tsang et al. 1990). The W oligonucleotide covers nucleotides -144 to -101 of the DRA promoter. The pBRm oligonucleotide contains a methylated sequence from pBR322 (Siegrist et al. 1993; Reith et al. 1994c). The pBR oligonucleotide contains the same pBR322 sequence in its unmethylated form.

\section{Purification and sequencing of the 75-kD polypeptide of $R F X$}

The procedure for affinity purification of RFX has been described in detail elsewhere (Durand et al. 1994). The purified fraction was estimated to be enriched $\sim 1500$-fold and contained $\sim 10 \mu \mathrm{g}$ of each of the RFX polypeptides. The purity and binding specificity of the purified RFX fraction was assayed by EMSA, cross-linking experiments, and SDS-PAGE as described previously (Durand et al. 1994). It contains no detectable X2-boxbinding proteins or X-box-binding proteins other than RFX. The tryptic peptide sequence was obtained as described (Rosenfeld et al. 1992) from $\sim 10 \mu \mathrm{g}$ of the $75-\mathrm{kD}$ polypeptide present in the purified RFX fraction.

\section{RNase protection experiments}

To synthesize the ${ }^{32} \mathrm{P}$-labeled probe used for RNase protection experiments, the BglI (nucleotide 153)-Xhol (nucleotide 739) fragment of RFX5 was inserted into a Bluescript plasmid (Stratagene) and transcribed with T7 RNA polymerase. For each sample, $20 \mu \mathrm{g}$ of total RNA (Chirgwin et al. 1979) was analyzed as described (Reith et al. 1994c).

\section{Cloning of RFX5 CDNAs from SJO and Ro}

Size selected $(>3 \mathrm{~kb})$ cDNA libraries were constructed as described from SIO and Ro RNA using SfiI adaptors and a modified Bluescript plasmid (pBlues-Sfi) containing a SfiI cloning cassette (Steimle et al. 1993). RFX5 cDNAs were selected by screening $10^{6}$ clones with an oligonucleotide situated immediately $3^{\prime}$ of the translation initiation codon (nucleotides 157-176). For each patient, one full-length cDNA was sequenced completely on both strands. For SIO, four additional cDNA clones were sequenced only in the region containing the 5 -nucleotide deletion. For Ro, three additional cDNA clones were sequenced only in the region containing the two point mutations.

\section{PCR analysis}

PCR experiments were performed in $50 \mu \mathrm{l}$ of $20 \mathrm{~mm}$ Tris- $\mathrm{HCl}$ (pH 8.3), $50 \mathrm{~mm} \mathrm{KCl}, 0.2 \mathrm{~mm}$ each dNTP, $1.5-2.5 \mathrm{~mm} \mathrm{MgCl}_{2}$ $500 \mathrm{ng}$ of genomic DNA, and 1.25 units of AmpliTaq polymerase (Perkin-Elmer Cetus). Touchdown PCR was performed for 30 cycles of $45 \mathrm{sec}$ at $94^{\circ} \mathrm{C}, 30 \mathrm{sec}$ at $60-50^{\circ} \mathrm{C}$ (first $10 \mathrm{cycles}$ ) and then at $50^{\circ} \mathrm{C}$ (last $20 \mathrm{cycles}$ ), and $30 \mathrm{sec}$ at $72^{\circ} \mathrm{C}$. The primers used to amplify the mutated region of the RFX5 gene in SJO were as follows. C15R, 5'-CGAGAATTCAGCTGTATCTCTACCTTC-3', contains an EcoRI site (underlined) and is situated at nucleotides $334-351$ of the RFX5 cDNA. N12R, 5'-GTC- 
GAATTCAGGGAAGATCTCTCTGATG-3', contains EcoRI and $B g$ III sites (underlined) and is situated at nucleotides 585566 of the RFX5 cDNA. PCR products were digested with EcoRI and $B g$ III, subcloned into Bluescript (Stratagene), and sequenced on both strands.

\section{Acknowledgments}

We are grateful to Pierre Chambon, Jean-Marc Egly, Vincent Moncollin, and Adrien Staub (Strasbourg) for having helped us to obtain tryptic peptide sequences for RFX, to R.S. Accolla, J.S. Lee, R.F. Margolskee, N. Reinsmoen, and A. Ziegler for generous gifts of BLS cell lines, plasmids, and antibodies; and to D. Wohlwend for help with FACScan analysis. This work was supported by the Swiss National Science Foundation and the Louis Jeantet Foundation. B. Durand was supported by a fellowship from the Association pour la Recherche sur le Cancer.

The publication costs of this article were defrayed in part by payment of page charges. This article must therefore be hereby marked "advertisement" in accordance with 18 USC section 1734 solely to indicate this fact.

\section{Note added in proof}

The RFX5 sequence has been submitted to the EMBL nucleotide sequence data base and assigned the accession number X85786. The $S$. cerevisiae RFX sequence referred to in the text /Yeast Genome Sequencing Project, accession no. U17246|.

\section{References}

Accolla, R.S. 1983. Human B cell variants immunoselected against a single antigen subset have lost expression of several Ia antigen subsets. /. Exp. Med. 157: 1053-1058.

Accolla, R.S., L. Scarpellino, G. Carra, and J. Guardiola. 1985. Trans-acting element(s) operating across species barriers positively regulate expression of major histocompatibility complex class II genes. J. Exp. Med. 162: 1117-1133.

Altschul, S.F., W. Gish, W. Miller, E.W. Myers, and D.J. Lipman. 1990. Basic local alignment search tool. I. Mol. Biol. 215: 403-410.

Andersson, G. and B.M. Peterlin. 1990. NF-X2 that binds to the DRA X2 box is activator protein 1 . Expression cloning of c-Jun. I. Immunol. 145: 3456-3462.

Bairoch, A. 1992. PROSITE: A dictionary of sites and patterns in proteins. Nucleic Acids Res. 20: 2013-2018.

Benichou, B. and J.L. Strominger. 1991. Class II-antigen-negative patient and mutant B-cell lines represent at least three, and probably four, distinct genetic defects defined by complementation analysis. Proc. Natl. Acad. Sci. 88: 4285-4288.

Bull, M., A. van Hoef, and J. Gorski. 1990. Transcription analysis of class II human leukocyte antigen genes from normal and immunodeficient B lymphocytes, using polymerase chain reaction. Mol. Cell. Biol. 10: 3792-3796.

Calman, A.F. and B.M. Peterlin. 1987. Mutant human B cell lines deficient in class II major histocompatibility complex transcription. I. Immunol. 139: 2489-2495.

- 1988. Evidence for a trans-acting factor that regulates the transcription of class II major histocompatibility complex genes: Genetic and functional analysis. Proc. Natl. Acad. Sci. 85: 8830-8834.

Casper, J.T., R.A. Ash, P. Kirchner, J.B. Hunter, P.L. Havens, and M.J. Chusid. 1990. Successful treatment with an unrelateddonor bone marrow transplant in an HLA-deficient patient with severe combined immune deficiency ("bare lympho- cyte syndrome"). J. Pediatr. 116: 262-265.

Charron, D.J. and H.O. McDevitt. 1979. Analysis of HLA-D region-associated molecules with monoclonal antibody. Proc. Natl. Acad. Sci. 76: 6567-6571.

Chirgwin, J.M., A.E. Przbyla, R.J. MacDonald, and J. Rutter. 1979. Isolation of biologically active ribonucleic acid from sources enriched in ribonuclease. Biochemistry 18: 5294 5299.

De Préval, C., B. Lisowska-Grospierre, M. Loche, C. Griscelli, and B. Mach. 1985. A trans-acting class II regulatory gene unlinked to the MHC controls expression of HLA class II genes. Nature 318: 291-293.

De Préval, C., M.R. Hadam, and B. Mach. 1988. Regulation of genes for HLA class II antigens in cell lines from patients with severe combined immunodeficiency. N. Engl. I. Med. 318: 1295-1300.

Durand, B., M. Kobr, W. Reith, and B. Mach. 1994. Functional complementation of $\mathrm{MHC}$ class II regulatory mutants by the purified X box binding protein RFX. Mol. Cell. Biol. 14: 6839-6847.

Emery, P., B. Mach, and W. Reith. 1993. The different level of expression of HLA-DRB1 and -DRB3 genes is controlled by conserved isotypic differences in promoter sequence. Hum. Immunol. 38: 137-147.

Field, J., J.-I. Nikawa, D. Broek, B. MacDonald, L. Rodgers, I.A. Wilson, R.A. Lerner, and M. Wigler. 1988. Purification of a RAS-responsive adenyl cyclase complex from Saccharomyces cerevisiae by use of an epitope addition method. Mol. Cell. Biol. 8: 2159-2165.

Gladstone, P. and D. Pious. 1978. Stable variants affecting B cell alloantigens in human lymphoid cells. Nature 271: 459-461.

Gönczy, P., W. Reith, E. Barras, B. Lisowska-Grospierre, C. Griscelli, M.R. Hadam, and B. Mach. 1989. Inherited immunodeficiency with a defect in a major histocompatibility complex class II promoter-binding protein differs in the chromatin structure of the HLA-DRA gene. Mol. Cell. Biol. 9: $296-302$.

Griscelli, C., B. Lisowska-Grospierre, and B. Mach. 1993. Combined immunodeficiency with defective expression in MHC class II genes. In Immunodeficiencies (ed. F.S. Rosen and M. Seligman), pp. 141-154. Harwood Academic Publishers, Chur, Switzerland.

Hadam, M.R., R. Dopfer, G. Dammer, H.-H. Peter, M. Schlesier, C. Müller, and D. Niethammer. 1984. Defective expression of HLA-D region determinants in children with congenital agammaglobulinemia and malabsorption: A new syndrome. In Histocompatibility testing 1984 (ed. E.D. Albert, M.P. Baur, and W.R. Mayr), pp. 645-650. Springer-Verlag, Berlin/ Heidelberg, Germany.

Hadam, M.R., R. Dopfer, G. Dammer, C. Derau, and D. Niethammer. 1986. Expression of MHC antigens in MHCclass-II-deficiency. In Progress in immunodeficiency research and therapy. II (ed. J. Vossen and C. Griscelli), pp. 89-96. Elsevier Science Publishers, Amsterdam, The Netherlands.

Hasegawa, S.L., J.L. Riley, J.H. Sloan, and J.M. Boss. 1993. Protease treatment of nuclear extracts distinguishes between class II MHC X1 box DNA-binding proteins in wild-type and class II-deficient B cells. I. Immunol. 150: 1781-1793.

Herrero Sanchez, C., W. Reith, P. Silacci, and B. Mach. 1992. The DNA binding defect observed in MHC class II regulatory mutants concerns only one member of a family of complexes binding to the $\mathrm{X}$ box of class II promoters. Mol. Cell. Biol. 12: 4076-4083.

Hooft van Huijsduijnen, R.A.M., X.Y. Li, D. Black, H. Matthes, C. Benoist, and D. Mathis. 1990. Co-evolution from yeast to 
mouse: cDNA cloning of the two NF-Y $(\mathrm{CP} 1 / \mathrm{CBF})$ subunits. EMBO I. 9: 3119-3127.

Hume, C.R. and J.S. Lee. 1989. Congenital immunodeficiencies associated with absence of HLA class II antigens on lymphocytes result from distinct mutations in trans-acting factors. Hum. Immunol. 26: 288-309.

Hume, C.R., L.A. Shookster, N. Collins, R. O'Reilly, and J.S. Lee. 1989. Bare lymphocyte syndrome: Altered HLA class II expression in B cell lines derived from two patients. Hum. Immunol. 25: 1-11.

Kara, C.J. and L.H. Glimcher. 1991. In vivo footprinting of MHC class II genes: Bare promoters in the bare lymphocyte syndrome. Science 252: 709-712.

- 1993. Three in vivo promoter phenotypes in MHC class II deficient combined immunodeficiency. Immunogenetics 37: 227-230.

Kobr, M., W. Reith, C. Herrero Sanchez, and B. Mach. 1990. Two DNA-binding proteins discriminate between the promoters of different members of the MHC class II multigene family. Mol. Cell. Biol. 10: 965-971.

Kouskoff, V., R.M. Mantovani, S.M. Candéias, A. Dorn, A. Staub, B. Lisowska-Grospierre, C. Griscelli, C. Benoist, and D. Mathis. 1991. NF-X, a transcription factor implicated in MHC class II gene regulation. I. Immunol. 146: 3197-3204.

Kozak, M. 1989. The scanning model for translation: An update. I. Cell Biol. 108: 229-24l.

Liou, H.-C., M.R. Boothby, and L.H. Glimcher. 1988. Distinct cloned class II MHC DNA binding proteins recognize the $\mathrm{X}$ box transcription element. Science 242: 69-71.

Liou, H.-C., M. Boothby, P.W. Finn, R. Davidon, N. Nabavi, N.J. Zelenik-Le, J.P.Y. Ting, and L.H. Glimcher. 1990. A new member of the leucine zipper class of proteins that binds to the HLA DRA promoter. Science 247: 1581-1584.

Lisowska-Grospierre, B., M.-C. Fondaneche, M.-P. Rols, C. Griscelli, and A. Fischer. 1994. Two complementation groups account for most cases of inherited MHC class II deficiency. Hum. Mol. Genet. 3: 953-958.

Mach, B., V. Steimle, and W. Reith. 1994. MHC class II deficient combined immunodeficiency: A disease of gene regulation. Immunol. Rev. 138: 207-221.

Mantovani, R., U. Pessara, F. Tronche, X.-Y. Li, A.-M. Knapp, J.-L. Pasquali, C. Benoist, and D. Mathis. 1992. Monoclonal antibodies to NF-Y define its function in MHC class II and alternate gene transcription. EMBO /. 11: 3315-3322.

Ono, S.J., V. Bazil, B.-Z. Levi, K. Ozato, and J.L. Strominger. 1991a. Transcription of a subset of human class II major histocompatibility complex genes is regulated by a nucleoprotein complex that contain c-fos or an antigenically related protein. Proc. Natl. Acad. Sci. 88: 4304-4308.

Ono, S.J., H.-C. Liou, R. Davidon, J.L. Strominger, and L.H. Glimcher. 1991b. Human X-box-binding protein 1 is required for transcription of a subset of human class II major histocompatibility genes and forms a heterodimer with c-fos. Proc. Natl. Acad. Sci. 88: 4309-4312.

Reith, W., S. Satola, C. Herrero Sanchez, I. Amaldi, B. LisowskaGrospierre, C. Griscelli, M.R. Hadam, and B. Mach. 1988. Congenital immunodeficiency with a regulatory defect in MHC class II gene expression lacks a specific HLA-DR promoter binding protein, RF-X. Cell 53: 897-906.

Reith, W., E. Barras, S. Satola, M. Kobr, D. Reinhart, C. Herrero Sanchez, and B. Mach. 1989. Cloning of the major histocompatibility complex class II promoter binding protein affected in a hereditary defect in class II gene regulation. Proc. Natl. Acad. Sci. 86: 4200-4204.

Reith, W., C. Herrero Sanchez, M. Kobr, P. Silacci, C. Berte, E. Barras, S. Fey, and B. Mach. 1990. MHC class II regulatory factor RFX has a novel DNA binding domain and a functionally indepedent dimerization domain. Genes \& Dev. 4: 1528-1540.

Reith, W., M. Kobr, P. Emery, B. Durand, C.A. Siegrist, and B. Mach. 1994a. Cooperative binding between factors RFX and $\mathrm{X} 2 \mathrm{bp}$ to the $\mathrm{X}$ and $\mathrm{X} 2$ boxes of MHC class II promoters. $I$. Biol. Chem. 269: 20020-20025.

Reith, W., C.A. Siegrist, B. Durand, E. Barras, and B. Mach. $1994 \mathrm{~b}$. The function of MHC class II promoters requires cooperative binding between factors RFX and NF-Y. Proc. Natl. Acad. Sci. 91: 554-558.

Reith, W., C. Ucla, E. Barras, A. Gaud, B. Durand, C. Herrero Sanchez, M. Kobr, and B. Mach. 1994c. RFXl, a transactivator of the hepatitis B virus enhancer I, belongs to a novel family of homodimeric and heterodimeric DNA-binding proteins. Mol. Cell. Biol. 14: 1230-1244.

Rosenfeld, I., J. Capdevielle, J.C. Guillemot, and P. Ferrara. 1992. In-gel digestion of proteins for internal sequence analysis after one- or two-dimensional gel electrophoresis. Anal. Biochem. 203: 173-179.

Seidl, C., C. Saraiya, Z. Osterweil, Y.P. Fu, and J.S. Lee. 1992. Genetic complexity of regulatory mutants defective for HLA class II expression. /. Immunol. 148: 1576-1584.

Shapiro, D.J., P.A. Sharp, W.W. Wahli, and M.J. Keller. 1988. A high efficiency HeLa cell nuclear transcription extract. DNA 7: $47-55$

Sicgrist, C.A., B. Durand, P. Emery, E. David, P. Hearing, B. Mach, and W. Reith. 1993. RFXl is identical to EF-C and functions as a transactivator of the hepatitis $B$ virus enhancer. Mol. Cell. Biol. 13: 6375-6384.

Sloan, J.H., S.L. Hasegawa, and J.M. Boss. 1992. Single base pair substitutions within the HLA-DRA gene promoter separate the functions of the $\mathrm{X} 1$ and $\mathrm{X} 2$ boxes. I. Immunol. 148: 2591-2599

Spickofsky, N., V. Canfield, and R.F. Margolskee. 1990. Procedures for constructing cDNA expression libraries in EpsteinBarr virus shuttle vectors capable of stable episomal replication. DNA Protein Eng. Techniques 2: 14-18.

Steimle, V., L.A. Otten, M. Zufferey, and B. Mach. 1993. Complementation cloning of an MHC class II transactivator mutated in hereditary $\mathrm{MHC}$ class II deficiency (bare lymphocyte syndrome). Cell 75: 135-146.

Steimle, V., C.A. Siegrist, A. Mottet, B. Lisowska-Grospierre, and B. Mach. 1994. Regulation of MHC class II expression by interferon-c mediated by the transactivator gene CIITA. Science 265: 106-109.

Stimac, E., S. Urieli-Shoval, S. Kempin, and D. Pious. 1991. Defective HLA DRA X box binding in the class II transactive transcripton factor mutant 6.1 .6 and in cell lines from class II immunodeficient patients. I. Immunol. 146: 4398- 4405.

Tabor, S. and C.C. Richardson. 1985. A bacteriophage T7 RNA polymerase/promoter system for controlled exclusive expression of specific genes. Proc. Natl. Acad. Sci. 82: 10741078.

Tsang, S.Y., M. Nakanishi, and B.M. Peterlin. 1990. Mutational analysis of the DRA promoter: cis-acting sequences and trans-acting factors. Mol. Cell. Biol. 10: 711-719.

Watson, A.J., F.H. Bach, R. DeMars, and I.S. Trowbridge. 1983. Detection of a novel human class II HLA antigen. Nature 304: 358-361.

Ziegler, A., H. Götz, J. Heinig, C. Müller, F.P. Thinnes, B. Uchanska-Ziegler, and P. Wernet. 1986. Analysis by sequential immunoprecipitations of the specificities of the monoclonal antibodies Tü22, Tü34, Tü35, Tü36, Tü37, Tü39, Tü43, Tü58, and Yd1/63:Hlk directed against human HLA class II antigens. Immunobiology 171: 77-92. 


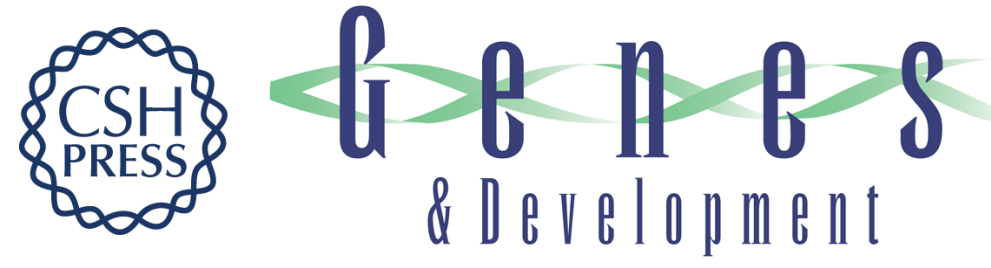

\section{A novel DNA-binding regulatory factor is mutated in primary MHC class II deficiency (bare lymphocyte syndrome).}

V Steimle, B Durand, E Barras, et al.

Genes Dev. 1995, 9:

Access the most recent version at doi:10.1101/gad.9.9.1021

References This article cites 55 articles, 33 of which can be accessed free at: http://genesdev.cshlp.org/content/9/9/1021.full.html\#ref-list-1

License

Email Alerting

Service

Receive free email alerts when new articles cite this article - sign up in the box at the top right corner of the article or click here.

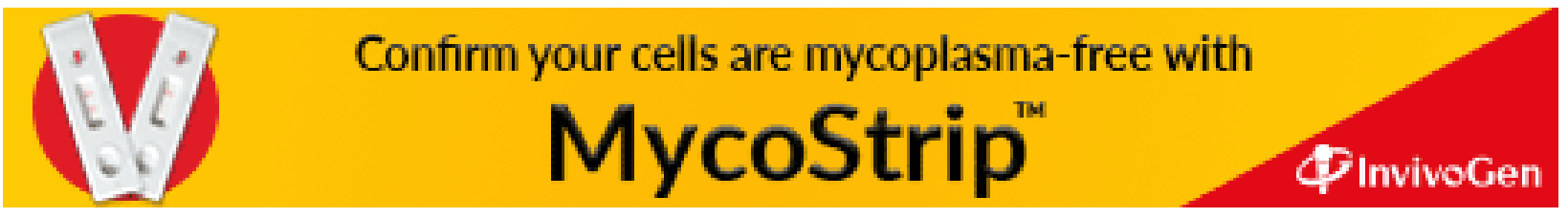

